\title{
ECONOMIC SLOWDOWN: AN EXPLANATION OF FALLING GROWTH RATE IN INDIA
}

\author{
Niket Sharma \\ Assistant Professor, Economics, JLU School of commerce and Economics, Jagran LakeCity \\ University, Bhopal
}

Article DOI: https://doi.org/10.36713/epra4167

\begin{abstract}
Economic growth of the country is part of economic development, as development is the phenomenon which follows growth and involves not only an increase in the total output but also a change in the structural and institutional factors that operate in economy and a welfare quotient. India has been observing an economic phenomenon called the stagflation, which has slowed economic growth in country and thus economic development

The objective of this paper is on growth witnessed in India and reasons why growth rate after displaying great momentum has reduced in past two years which has also reduced the level of development. Paper has also explored various measures of the economic development in an economy. The paper tries to estimate the reasons for stagflation in the economy and probable solutions to it.
\end{abstract}

KEYWORDS: economic development, economic growth, stagflation,

\section{INTRODUCTION TO ECONOMIC DEVELOPMENT}

Economic growth of a country can be defined as increase in the aggregate output, increase in the productive capacities, increase in the per capita income of the country, etc. it can be measured using country's gross national product (GNP), or country's gross domestic product (GDP), usually for closed economy where foreign sector is absent gross domestic product is used to calculate the country's growth, gross national product is used to calculate the growth of country involving its foreign sector. Since the foreign sector of a country is affected by various variables which are determined by global economic factors which are not under the control of a country, gross domestic product is taken to be good measure of economic growth because it excludes the extraneous variable of foreign sector.

Economic growth of the country is part of economic development, as development is the phenomenon which follows growth and involves not only an increase in the total output but also a change in the structural and institutional factors that operate in economy and a welfare quotient. Economic growth is steady and continuous change in the economy whereas economic development is sudden discontinuous change in the economic system of the country. The focus of this paper is on growth witnessed in India and reasons why growth rate after displaying great momentum has reduced in past two years which has also reduced the level of development.

There are various methods developed over period of time to calculate the economic development in the country one of the most common method of calculating development is by taking into consideration the economic growth in terms of GDP of the country, which has been done in this paper, also used by the world bank to categorize various countries into low income, lower middle income, upper middle income and high income countries. Others methods include the 


\section{EPRA International Journal of Research and Development (IJRD) \\ Volume: 5 | Issue: 3 | March 2020 \\ - Peer Reviewed Journal}

physical quality of life index give by Moris D Moris in 1970s which take into consideration literacy, infant mortality and life expectancy.perhaps one of the most composite and inclusive development index is the human development index of UNDP given by mehboob-ul-haq and Amartya Sen in 1990s which is based upon literacy, life expectancy and standard of living in the country. In 2010 multi-dimensional poverty index by oxford poverty and human development programme. Apart from the usual indices there are newer indices such as gross national happiness launched by Bhutan which measures development on basis of pristine enviroment, self sufficiency, good governance and preservation and promotion of Bhutan's culture.

\section{OBJECTIVE OF THE RESEARCH}

Objective of the research is to analyse the growth rate of GDP of India in past 10 years and try to interpret the reasons why economic growth has fallen in 2018-2019, eliminate the factors that have no effect on the currently falling growth rate and to discuss in detail the problem of stagflation plauging economic growth in India and suggest probable suggestions to it.

\section{REVIEW OF LITERATURE}

Mukherjee Rahul (2009) titled 'the state, economic growth and development in India' explores how growth rate increased in india in phased manner comprising of three phases: 1950-1970s, 1970-1990, 1990-2008. Paper highlight importance of the social and political factors that affceted India's growth and how. Challenges to economic growth in India according to paper are slow output growth of agriculture, bottlenecks in expansion of manufacturing sector, role of trade unions in business sector and lack of human resource development. The paper has not included factors that are causing fall in economic growth at present also it has given too much importance on factros whoes true effect can be seen in long run, factors affecting short run growth have been ingnored.

\section{RESEARCH METHODOLOGY}

The paper is based descriptive research which uses data secured from secondry sources, for making graphs, table and analysis of trends microsoft Excel is used as research tool along with paint tool.

\section{Economic growth}

Table-1

\begin{tabular}{|l|l|}
\hline Year & GDP \\
\hline 2007 & 9.8 \\
\hline 2008 & 3.9 \\
\hline 2009 & 8.5 \\
\hline 2010 & 10.3 \\
\hline 2011 & 6.6 \\
\hline 2012 & 5.5 \\
\hline 2013 & 6.4 \\
\hline 2014 & 7.4 \\
\hline 2015 & 8.0 \\
\hline 2016 & 8.2 \\
\hline 2017 & 7.2 \\
\hline 2018 & 6.8 \\
\hline 2019 & 5.0 \\
\hline
\end{tabular}

Source: tradingeconomics.com 


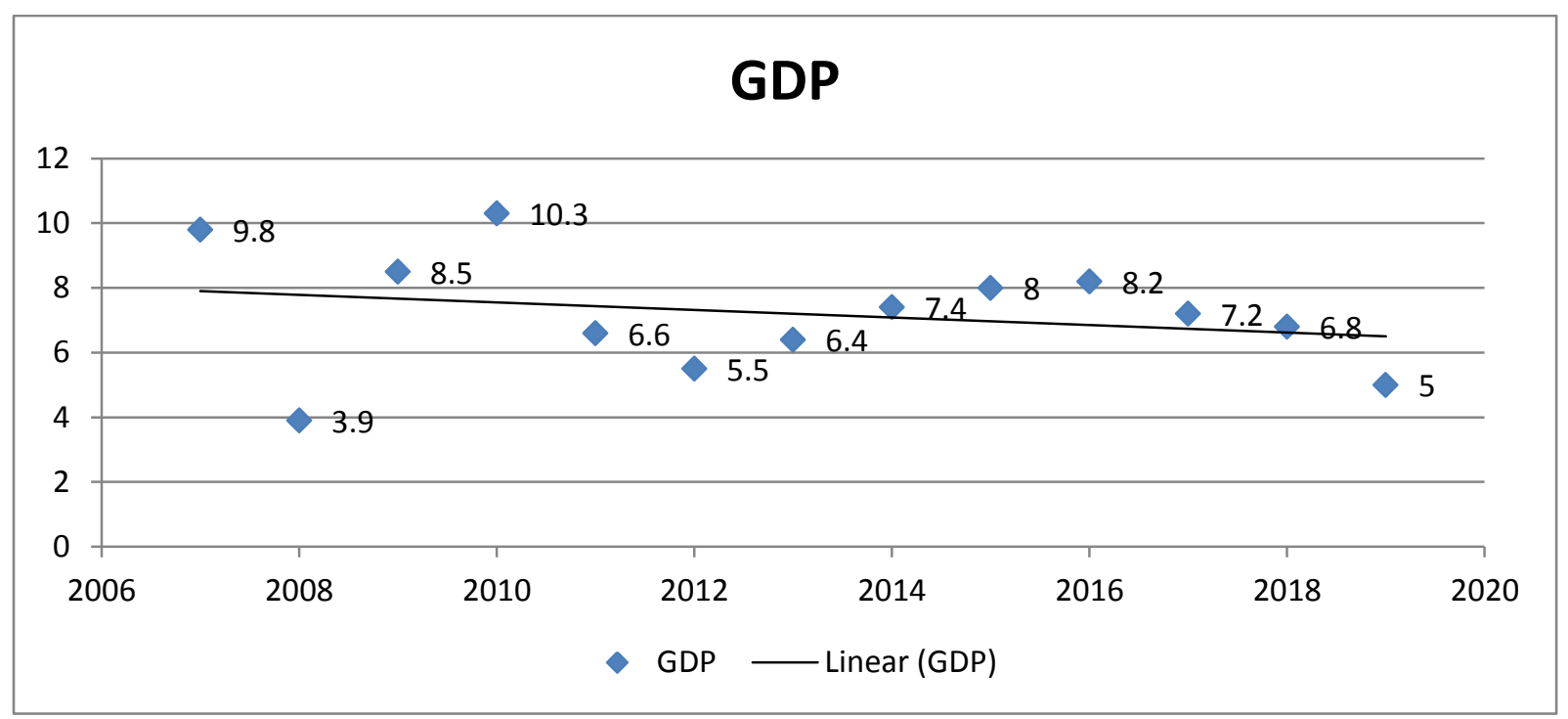

Figure-1

Various factors that affect the economic growth and thus development of the country can be categorized into structural, institutional, political, social, etc.

- India economy is characterized by presence of three sectors: primary (agricultural sector), secondary (manufacturing sector), tertiary (service sector), structural problem in growth is created by presence of underdeveloped manufacturing sector relative to the agricultural and service sector which not only reduce employment prospects and output in the economy but also causes country to be dependent on foreign imports.

- Second factor that affect growth of India is the amount of control over economic forces exerted by central bank of our country the reserve bank of India, which through its quarterly monetary policy review affects the supply of money in economy thus affecting price levels and demand, which in turn affects output and employment.

- Political factors provide stability to the country for its market mechanism to follow freely and self adjust to reach equilibrium. India comprises of around $17.5 \%$ of world population, it is home to
1.32 billion people who contribute to the economic growth of the country however there are some bottlenecks in their contributions such as lack of skill and illiteracy, poor health, etc.

\section{ELIMINATING ROLE OF FLUCTUATIONS IN OIL PRICES ON GROWTH RATE}

Availability of resources also affects the economic growth most important of them is the oil which forms largest component of India's import, India imports $82 \%$ of its total oil demand in 2018 it imported 205.3 Mt of oil from other countries, changes in prices of oil affects the creates a supply shock in India causing economic growth to suffer. In 2010 petrol subsidy ended in India and in 2014 diesel subsidy was also abolished by government which reduced the effect of fluctuations in oil prices on India's economic growth however prices of diesel and petrol continue to affect the total output in three sectors of economy, due to their dependence on machinery which make extensive use of these products. 


\section{EPRA International Journal of Research and Development (IJRD) \\ Volume: 5 | Issue: 3 | March 2020 \\ - Peer Reviewed Journal}

Table-2

\begin{tabular}{|c|c|c|}
\hline years & GDP & Average oil prices \\
\hline 2007 & 9.8 & $\$ 72.34$ \\
\hline 2008 & 3.9 & $\$ 99.67$ \\
\hline 2009 & 8.5 & $\$ 61.95$ \\
\hline 2010 & 10.3 & $\$ 79.48$ \\
\hline 2011 & 6.6 & $\$ 94.88$ \\
\hline 2012 & 5.5 & $\$ 94.05$ \\
\hline 2013 & 6.4 & $\$ 97.98$ \\
\hline 2014 & 7.4 & $\$ 93.17$ \\
\hline 2015 & 8.0 & $\$ 48.72$ \\
\hline 2016 & 8.2 & $\$ 43.58$ \\
\hline 2017 & 7.2 & $\$ 50.84$ \\
\hline 2018 & 6.8 & $\$ 64.90$ \\
\hline 2019 & 5.0 & $\$ 57.05$ \\
\hline
\end{tabular}

Source: Oil prices data from Macrotrends.com

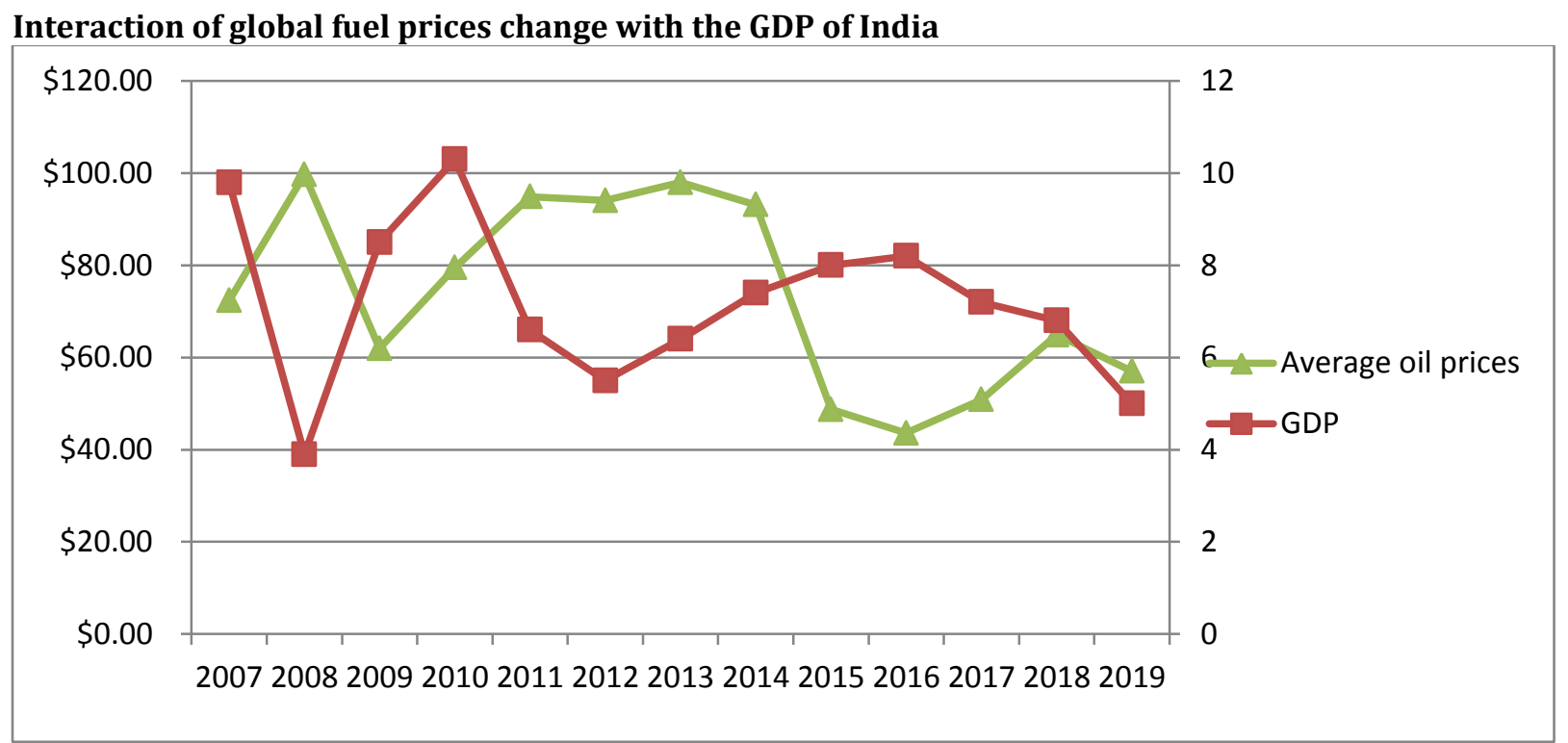

Figure-2

source: based on above table

From the above table it is clear that in past steep fall in prices of oil resulted in the economic growth, and increase in the prices of oil and oil products led to decrease in the GDP of the country, however the recent slowdown of economic growth cannot be attributed to change in the oil prices which themselves seen to be falling.

\section{CAUSE OF FALLING ECONOMIC GROWTH IN INDIA}

India characterized with high unemployment rate of $7.7 \%$ of labor force in December 2019, in October 2019 it had an unemployment rate of $8.2 \%$ highest in past three years, in December 2019 another economic phenomenon that coupled high unemployment was high rate of inflation which stood at $7.35 \%$ which was highest witnessed in past 5 years. The coupling of these two phenomenon in the economy i.e. high rates of unemployment and high rates of inflation gives rise to another economic phenomenon called the stagflation, it is a paradoxical situation in economy where relation between inflation and rate of unemployment which is usually inverse in nature changes to become direct and leaves many economists in jitters about the ways to correct the functioning of economy and ensure growth. 


\section{REASONS OF STAGFLATION IN THE COUNTRY}

1. POLITICAL REASONS: Long political process of elections which have been continuing since beginning of the financial year 2018 when there were elections in the heartland states of M.P., Chattisgarh, Rajsathan. Year 2019 also have seen several states going into elections also there was election at the union level, all these election causes loss of man days due to campaigning processes which are composed of blue collared labour in urban areas and petty agriculturists in the rural areas, which results in the reduction in the output.

\section{FLUCTUATIONS IN EXTERNAL} SECTORS: Spill over of the trade war between USA and China, ending of preferential trade status of India by the President of the United States Donald Trump in June 2019 affected Indian exports which reduced total output in the country.

3. UNCERTAINITY IN AUTOMOBILE SECTOR: Rise of ambiguity in the automobile sector due to possible launch of BSvi in 2020 which will cause ban on the sales of BSiv variant car engines, which has led people to defer their purchases till the ambiguity is cleared, automobile being the one of the largest consumer of steel, oil products, etc. has caused reduction in the growth rate of index of industrial production which fell by 4\% in September 2019 and rose only by $1.8 \%$ in December 2019 .

4. CLIMATIC FACTORS: Erratic Climatic factors also have slowed output growth in the country in March 2019 around $42 \%$ of country was facing drought, in October states like kerela, Uttrakhand, Maharastra ,Assam, Bihar, Karnataka were reeling under excessive flooding which caused huge economic loss for the country reducing the aggregate supply in the economy.

\section{PROBLEMS OF BANKING SECTOR:} Restructuring of Indian banking system by ensurusing capital adequacy ratio at appropriate level under Basel III, government infused capital into banking system which reduced NPAs to 9.1\% in September 2019 from $11.2 \%$ September 2018, which partially reduced liquidity and output in the economy.
6.GOVERNMENTAL POLICIES: Government policies also have affected the economic growth and caused stagflation, the demonetization announced in 2016 did reduce the liquidity and output in the however its effect did not appear in 2017-2018 because of announcement of new pay commission by governments which by multiplier effect partially reduced the deficient demand in the economy, loss due to demonetization pegged at over INR 1 lakh crore (economictimes), amending article 370 by government in 2019 has caused loss of $\$ 2.4$ billion to state of Jammu and Kashmir (business-standard.com) due to reduction in output and trade, citizenship amendment act of 2019 has caused economic loss of INR 1000 crore to state of Assam only the loss due to wide spread protests in various states have not been yet estimated. All these facts combined together are causing the economic slowdown and stagflation in the country.

\section{WAYS TO CORRECT STAGFLATION}

1. Increase demand, 2. Increase supply, 3. Labour policy, 4. Price policy

Out of the above four ways tackle labour policy deals with fixing the highest wage rate in order to prevent inflation in the economy, and price policy refers to policy of price ceiling of goods and services in the economy both these policy are more possible in a communist regime like China than in democratic regime like India. Thus the only two ways to tackle stagflation in India can be increasing demand or increasing supply.

\section{Case-1: Increasing demand}

Keynes stressed upon the importance of demand in his general theory of employment, interest and money that is increasing demand will increase output and employment. Increasing demand however also increases the prices in short run, which increases the inflation in the country, for country like India which have a quantum of population below poverty line increase in inflation even in short run can be ruinous, thus increasing demand by direct cash transfers schemes such as NYAY scheme, PMKISAN scheme, KALIA scheme (Odisha Government), Rythu Bandhu scheme ( Telangana Government), etc . Will not necessarily produce the desired results in short run. 


\section{EPRA International Journal of Research and Development (IJRD)

Figure-3

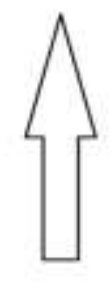

PRICES

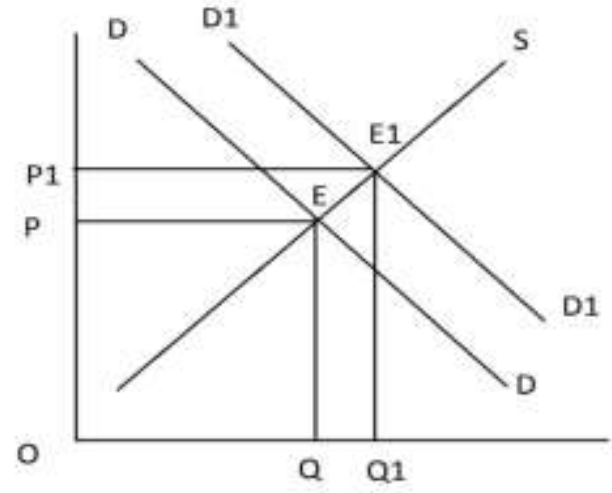

OUTPUT

\section{Case 2: supply increase}

Another way to tackle stagflation in the economy is to increase the supply of goods and services in the economy, which unlike demand increase will first lead to reduction in the prices, which increase demand and thus unemployment will be reduced and economic growth will originate, one of the easiest way to do so is to reduce taxes, which affect the ability and willingness of people to work, save and invest. Reducing taxes will motivate industrialists and entrepreneurs to expand production and thus employ more labour and increase the output in the economy leading to growth.

Figure-4

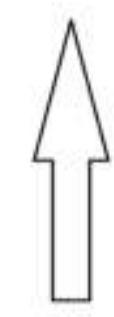

PRICES

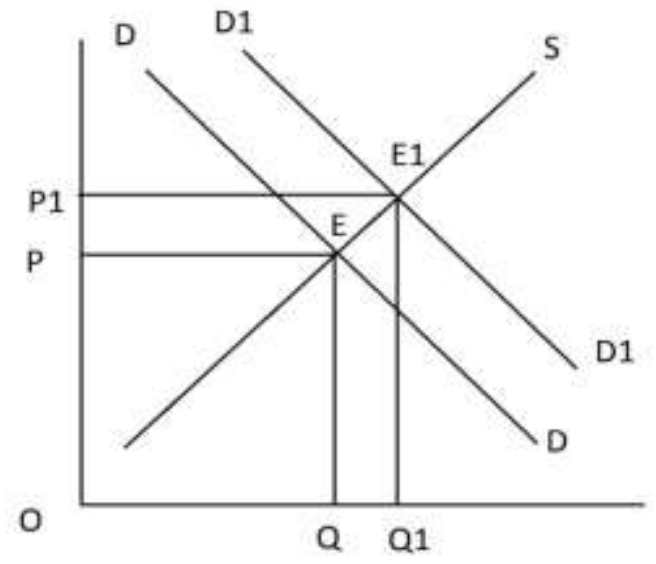

OUTPUT

One way to increase supply is to reduce the taxes, taxes as we know that affects the ability and willingness to work save and invest in the economy, reducing the tax rates will serve as impetus to increase production which increase supply which not only reduces the level of unemployment in the economy but also reduce inflation in short run and thus enable economy to return back to growth path.
To conclude it can be said that India, to achieve its vision 2022 i.e. to make Itself free from corruption, communalism, casteism, poverty, terrorism and ensure cleanliness is passing through a phase of transition, there are several policy decisions are taking place, some of which have been pending since independence, some of these measures are very bold and progressive, and there is no denying the fact that some of them have 


\section{EPRA International Journal of Research and Development (IJRD)

created some sense of instability in short run, however the true effect of these changes can be witnessed only in long run. One thing that can be done is to ensure the transition process should have least cost disadvantage for the general populace specially the disadvantage section of the society.

\section{SCOPE FOR FURTHER RESEARCH}

Further research may be conducted to find how fast supply changes in relation to changes in taxes and can it actually tackle stagflation in short run

\section{GLOSSARY}

- Bsiv- Bharat Stage phase 4

- Bsvi- Bharat Stage phase 6

- GDP-Gross domestic Product

- GNP- Gross National Product

- PMKISAN- Prime minister Kishan Samman Nidhi

- KALIA- Krushak assistance for Livelihood and income augmentation

- UNDP- United Nations Development Programme

\section{REFERENCES}

1. Jhingan.M.L. (2007) 'The Economics of development and planning' (39 $9^{\text {th }}$ edition), Vrinda Publications (P) Ltd., 3-22ii

2. Mukherji, Rahul(2009) 'The State, Economic Growth, and Development in India', India Review, 8:1,81-106

3. Seth. M.L. (2009) 'MacroEconomics'( $27^{\text {th }}$ edition), Laxmi Narayan Agarwal, 428-430

\section{Websites referred:}

1. https://www.businesstoday.in/current/economypolitics/us-to-end-preferential-trade-treatment-for-indiafrom-june-5-what-it-means-and-will-it-affectcountry/story/352851.html

2. https://www.business-standard.com/article/economypolicy/kashmir-sees-over-2-4-billion-losses-since-article370-was-amended-119121800662_1.html_Business Standards

3. https://economictimes.indiatimes.com/news/economy/poli cy/demonetisation-all-cost-and-little-

benefit/articleshow/65639832.cms?from $=m d r$ Economic times

4. https://www.macrotrends.net/2516/wti-crude-oil-prices10-year-daily-chart Macrotrends.com

5. https://tradingeconomics.com/india/industrialproduction Tradingeconomics.com

6. https://timesofindia.indiatimes.com/india/tourism-inassam-suffers-rs-1000-crore-loss-due-tocaa/articleshow/73048089.cms Times of India

7. https://www.pmkisan.gov.in/

8. https://economictimes.indiatimes.com/news/politics-andnation/odisha-reduces-kalia-assistance-to-rs-4000-fromrs-10000/articleshow/72416518.cms
9. https://www.financialexpress.com/economy/rythubandhu-scheme-telangana-releases-rs-5100-crore-forfarmers/1832259/

10. https://timesofindia.indiatimes.com/business/indiabusiness/banks-npas-decline-for-first-time-in-sevenyears/articleshow/72961638.cms

11. https://www.business-standard.com/article/currentaffairs/nearly-half-of-india-under-drought-40population-severely-affected-119040300143_1.html

12. https://economictimes.indiatimes.com/markets/stocks/ne ws/retail-inflation-hits-over-5-year-high-experts-say-6will-be-the-newnormal/articleshow/73231448.cms? from $=m d r$

13. https://niti.gov.in/writereaddata/files/new_initiatives/NIT I\%20VC\%20Presentation $\% 20$ Governors $\% 20$ Conference _Oct12_En.pdf 